Supplement of Atmos. Chem. Phys., 14, 9831-9854, 2014

http://www.atmos-chem-phys.net/14/9831/2014/

doi:10.5194/acp-14-9831-2014-supplement

(C) Author(s) 2014. CC Attribution 3.0 License.

(c) (i)

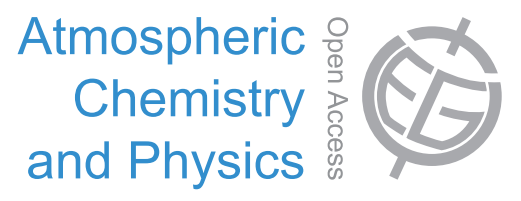

Supplement of

\title{
Cloud droplet activity changes of soot aerosol upon smog chamber ageing
}

C. Wittbom et al.

Correspondence to: C. Wittbom (cerina.wittbom@nuclear.lu.se) 


\section{Supplement}

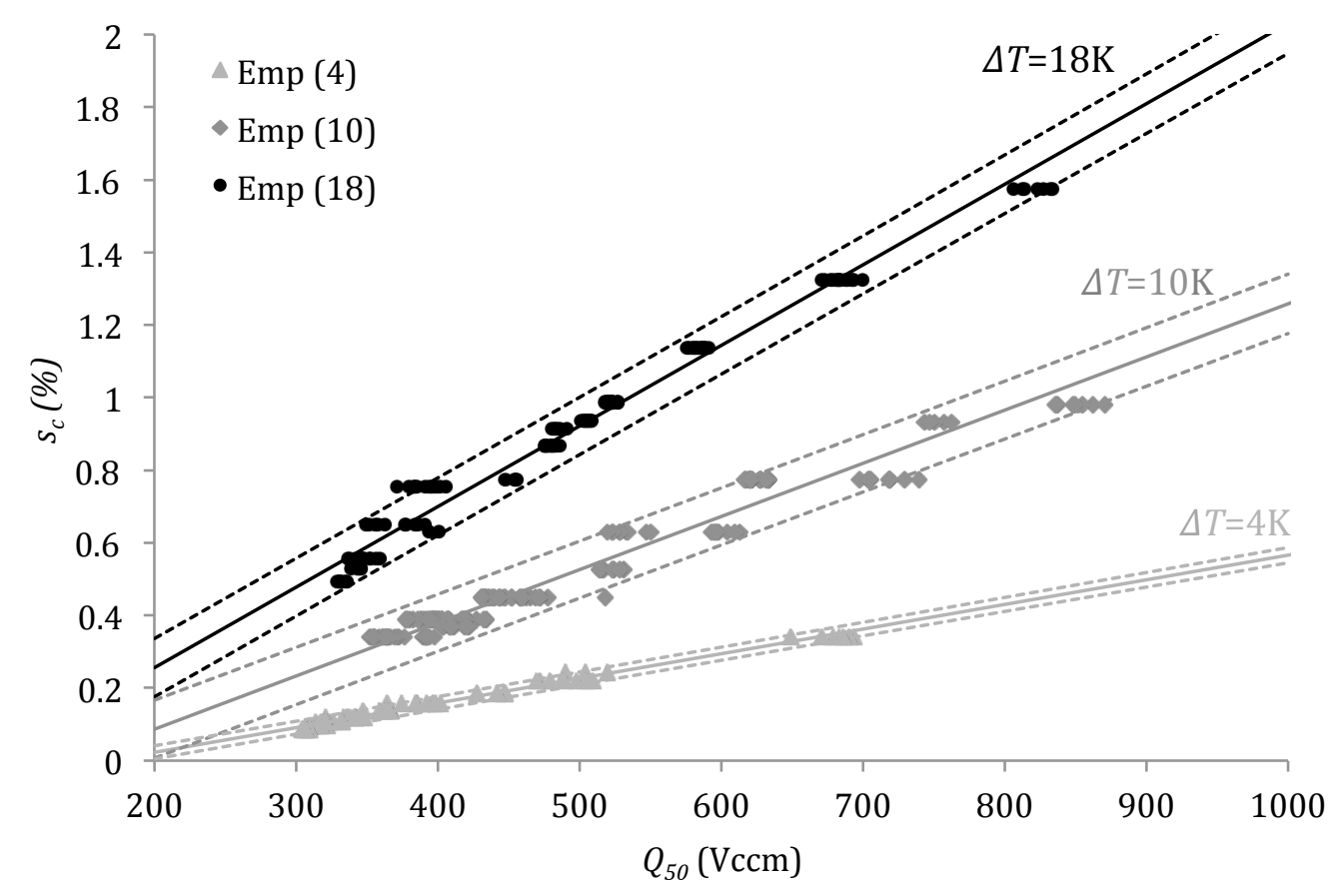

4 Figure $\mathrm{S}$ 1. Illustration of calibration measurements performed with AS (for $\Delta T=4 \mathrm{~K}, 10 \mathrm{~K}$ 5 and $18 \mathrm{~K})$ and sucrose $(\Delta T=18 \mathrm{~K})$ for one of the CCNC. Measured values (markers) and the 6 corresponding fit (lines) with 95\% confidence intervals (dotted lines) for the three different $7 \Delta T$ used in the study. The slope and intercept of the $18 \mathrm{~K}$ line are 0.00221984 and -

80.1882434 ; the slope and intercept for the $10 \mathrm{~K}$ are 0.00146469 and -0.2063209 ; and for the 4 $9 \mathrm{~K}$ the slope and intercept are 0.00067888 and -0.1128603 . 
1 Table S 1. An example of the DMA-APM settings (without the thermodenuder) used during 2 DEP2. Shown here is the particle mobility diameter $\left(d_{\mathrm{m}}\right)$, the peak of the mass distribution for 3 the fresh $\left(\mathrm{V}_{\text {fresh soot }}\right)$ and processed soot $\left(\mathrm{V}_{\text {processed soot }}\right)$, the rotational speed and voltage scan4 range of the APM as well as the resolution parameter for the fresh $\left(\lambda_{\text {fresh soot }}\right)$ and the 5 processed soot $\left(\lambda_{\text {processed soot }}\right)$.

\begin{tabular}{ccccccc}
\hline $\begin{array}{c}d_{\mathrm{m}} \\
(\mathrm{nm})\end{array}$ & $\begin{array}{c}\mathrm{V}_{\text {fresh soot }} \\
(\mathrm{V})\end{array}$ & $\begin{array}{c}\mathrm{V}_{\text {processed soot }} \\
(\mathrm{V})\end{array}$ & $\begin{array}{c}\text { APM Rotational } \\
\text { speed } \\
(\mathrm{rpm})\end{array}$ & $\begin{array}{c}\text { APM Voltage } \\
\text { scan-range } \\
(\mathrm{V})\end{array}$ & $\lambda_{\text {fresh soot }}$ & $\lambda_{\text {processed soot }}$ \\
\hline 90 & 50 & 100 & 5500 & $20-160$ & 0.062 & 0.125 \\
150 & 140 & 420 & 5000 & $40-400$ & 0.074 & 0.223 \\
200 & 180 & 620 & 3000 & $50-500$ & 0.061 & 0.210 \\
300 & 260 & 900 & 3000 & $500-2000$ & 0.049 & 0.170 \\
\hline
\end{tabular}




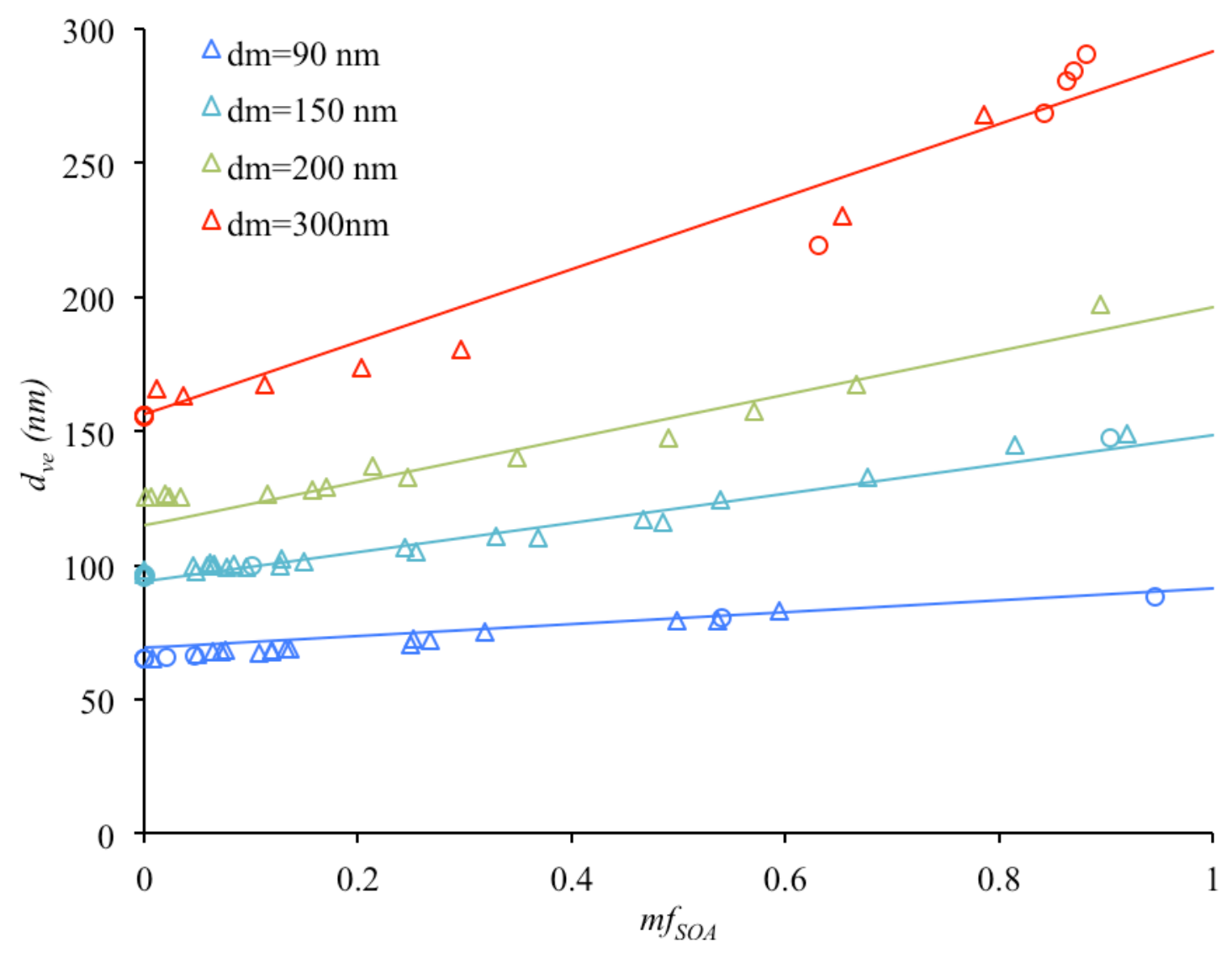

$\frac{1}{2}$

3 Figure S 2. Empirically derived volume equivalent diameters $\left(d_{\mathrm{ve}}\right)$ for mobility diameters $\left(d_{\mathrm{m}}\right)$ 4 of $90 \mathrm{~nm}$ (red), $150 \mathrm{~nm}$ (green), $200 \mathrm{~nm}$ (purple) and $300 \mathrm{~nm}$ (blue). Diesel exhausts particles 5 (DEP1, 2 and 3, triangles) as well as flame soot particles (FSP1, circles) with a primary 6 particle diameter $\left(d_{\mathrm{pp}}\right)$ of $28 \mathrm{~nm}$ are used for the fitting. The estimated $d_{\mathrm{ve}}$ (lines) is calculated 7 from measured $d_{\mathrm{m}}$ and the SOA mass fraction $\left(\mathrm{mf}_{\mathrm{SOA}}\right)$ of the particles (see Eq. (11) and (12) 8 in Sect.5.3). 


\section{ADCHAM model simulations of the DEP2 experiment}

2 Here we describe how the Aerosol Dynamics, gas- and particle- phase chemistry model for

3 laboratory CHAMber studies (ADCHAM; Roldin et al., 2014) was used to simulate the gas-

4 phase chemistry, secondary organic aerosol (SOA) formation and its properties during the

5 DEP2 experiment. For the model simulations it is assumed that the gas-phase chemistry in the

6 chamber is primarily driven by the $\mathrm{NO}_{\mathrm{x}}$ emissions from the Euro II Diesel Passenger Vehicle,

7 the added light-aromatic precursors (toluene and m-xylene), and the alkene, alkyne and

8 aldehyde emissions from the diesel vehicle. The absolute alkene, alkyne and aldehyde

9 concentrations in the chamber $\left(c_{i}\right)$ (Table S2), are estimated by scaling their concentrations

10 reported by Schauer et al. (1999) ( $\left.c_{i, \text { Schauer }}\right)$ with our measurements of light-aromatic

11 compounds (C6-C9) from the DEP4 experiment (Eq. (S1)).

$c_{i}=c_{i, \text { Schauer }} \cdot \frac{[\text { light-arom. }]_{\mathrm{DEP} 4}}{[\text { light-arom. }]_{\text {Schauer }}}$

Table S 2. Estimated initial alkene, alkyne and aldehyde concentrations in the Teflon chamber

16 during the DEP2 and DEP4 experiments.

\begin{tabular}{ll}
\hline & $c_{i}(\mathrm{ppbv})$ \\
\hline Alkenes & 13.03 \\
Ethene & 0.79 \\
Propene & 0.20 \\
Trans-2-butene & 0.40 \\
Cis-2-butene & 0.87 \\
Isobutene & 0.10 \\
3-methyl-1-butene & 0.16 \\
2-methyl-1-butene & 0.24 \\
1,3-butadiene & $\mathbf{1 5 . 7 9}$ \\
Total & \\
Alkynes & \\
Ethyne & 7.54 \\
\hline
\end{tabular}


Aldehydes

Formaldehyde

Acetaldehyde

40.48

Propanal

Total

\subsection{5}

1

\section{Gas-phase chemistry}

3 In the model the simulations start with estimated concentrations of alkene, alkyne and

4 aldehyde (Table S2) and the measured initial $\mathrm{NO}$ and $\mathrm{NO}_{2}$ concentration of 420 and $150 \mathrm{ppb}$,

5 respectively. Between 20 and 90 minutes after the input of diesel vehicle emissions $\mathrm{O}_{3}$ are

6 slowly added ( $\sim 5.3 \mathrm{ppb} / \mathrm{min})$ to the modelled chamber in order to capture the conversion of

$7 \mathrm{NO}$ to $\mathrm{NO}_{2}$ prior to the onset of the UV-light (see Fig. S3a). 30 minutes before the UV-lights

8 are turned on $430 \mathrm{ppb}$ of toluene and $310 \mathrm{ppb}$ of $m$-xylene are added to the chamber.

9 Unfortunately the toluene and $m$-xylene concentrations were not measured during the DEP2

10 experiment. Thus, the concentrations were estimated based on the GC-MS measurements

11 during the DEP4 experiment, in which the same amount of toluene and $m$-xylene were

12 injected. The gas-phase chemistry in the chamber was modelled with the kinetic mechanism

13 from Master Chemical Mechanism v3.2 (MCMv3.2; Jenkin et al., 2003; Bloss et al., 2005 and

14 b), including all compounds in Table $\mathrm{S} 2$, toluene, $m$-xylene and all inorganic reactions (in total 772 compounds and 2446 reactions). Bloss et al. (2005a and b) have shown that the MCMv3.1 generally overestimates the ozone concentration and underestimates the $\mathrm{OH}$ concentration during oxidation of light aromatic compounds (e.g. xylene and toluene). Similar model and measurement discrepancy was also observed by Roldin et al. (2014) when simulating the photooxidation of $m$-xylene in the $6 \mathrm{~m}^{3}$ Teflon chamber used in the present study. In order to improve the model performance Bloss et al. (2005) and Roldin et al. (2014)

21 included an artificial $\mathrm{OH}$ source after the UV-lights are turned on. In this work the same artificial OH source rate are used as in Roldin et al. (2014) of $10^{8} \mathrm{~cm}^{-3} \mathrm{~s}^{-1}$. With the artificial

$23 \mathrm{OH}$ source the model better captures the observed temporal evolution of the $\mathrm{NO}$ and $\mathrm{O}_{3}$

24 concentrations. 


\section{Chamber wall effects}

2 The ADCHAM model explicitly treats the deposition of particles and gases onto the Teflon 3 walls, the mass transfer limited diffusion of gases across a thin laminar layer $(\Delta x)$ adjacent to 4 the Teflon walls, and the mass transfer of organic compounds to and from the particles 5 deposited on the chamber walls. Table S3 list the values used for different model parameters 6 related to the mass transfer to and from the Teflon walls. See Roldin et al. (2014) for detailed 7 information about how all these parameters are used in ADCHAM. The parameter values 8 were adopted from Roldin et al. (2014) in which ADCHAM was used to simulate the SOA

9 formation during a $m$-xylene experiment in the Teflon chamber in the Aerosol Laboratory at 10 Lund University.

11 Table S 3. Parameters used to calculate the chamber wall effects in ADCHAM.

\begin{tabular}{|c|c|c|}
\hline Parameter & Description & Value (unit) \\
\hline$V_{0}$ & Initial chamber volume & $5.95\left(\mathrm{~m}^{3}\right)$ \\
\hline$\Delta V / \Delta t$ & Volume loss rate in chamber & $-0.4^{\#}\left(\mathrm{~m}^{3} \mathrm{~h}^{-1}\right)$ \\
\hline$V_{t}$ & Chamber volume at time $t$ & $V_{0}+\Delta V / \Delta t \cdot t$ \\
\hline $\bar{E}$ & Mean electrical field strength & $50 \cdot V_{0} / V_{t}\left(\mathrm{~V} \mathrm{~cm}^{-1}\right)$ \\
\hline$u^{*}$ & Friction velocity & $0.25^{\#}, 0.05^{\# * *}\left(\mathrm{~m} \mathrm{~s}^{-1}\right)$ \\
\hline$k_{g, w}$ & $\begin{array}{l}\text { First order loss rate from the near } \\
\text { wall gas phase to the walls }\end{array}$ & $1 / 15\left(\mathrm{~s}^{-1}\right)$ \\
\hline$k_{w, g}$ & $\begin{array}{l}\text { Desorption rate from the chamber } \\
\text { wall Teflon surfaces }\end{array}$ & $k_{w, g, i}=\frac{k_{g, w}}{\left(R T / p_{0, i} C_{w} /\left(M_{w} \gamma_{w, i}\right)\right.}\left(\mathrm{s}^{-1}\right)$ \\
\hline$C_{w, i}$ & $\begin{array}{l}\text { Effective wall equivalent mass } \\
\text { concentration of compound } i\end{array}$ & $\left(\mathrm{~mol} \mathrm{~m}^{-3}\right)$ \\
\hline$M_{w}$ & $\begin{array}{l}\text { Average molar mass of the Teflon } \\
\text { film }\end{array}$ & $(\mathrm{mol})$ \\
\hline$\gamma_{w, i}$ & $\begin{array}{l}\text { Activity coefficient of compound } i \\
\text { in the Teflon film }\end{array}$ & \\
\hline$p_{0, i}$ & $\begin{array}{l}\text { Pure liquid saturation vapour } \\
\text { pressure of compound } i\end{array}$ & $(\mathrm{~Pa})$ \\
\hline$C_{w} /\left(M_{w} \gamma_{w, i}\right)$ & $\begin{array}{l}\text { Measureable parameter, for uptake } \\
\text { on Teflon walls (see Matsunaga } \\
\text { and Ziemann, 2010) }\end{array}$ & $\left.100(\mu \mathrm{mol} \mathrm{m})^{-3}\right)^{* * *}$ \\
\hline$\Delta \mathrm{x}$ & $\begin{array}{l}\text { Laminar layer adjacent to the } \\
\text { Teflon walls }\end{array}$ & $10^{-3}(\mathrm{~m})$ \\
\hline$E_{\text {HONO }}$ & $\begin{array}{l}\text { HONO wall emissions during } \\
\text { photooxidation }\end{array}$ & $4.6 \times 10^{8}$ molecules $\mathrm{cm}^{-2} \mathrm{~s}^{-1}$ \\
\hline
\end{tabular}


a)
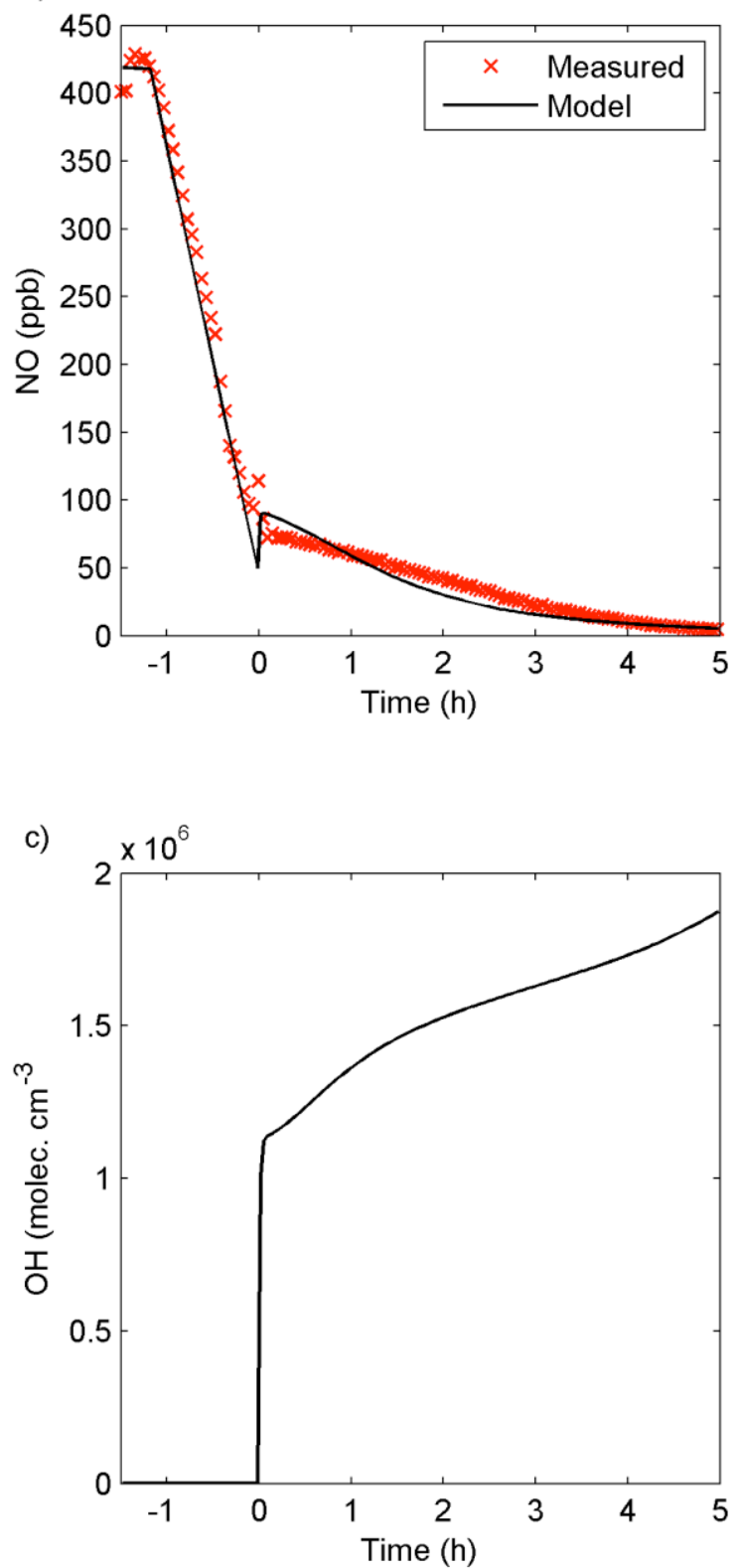

b)

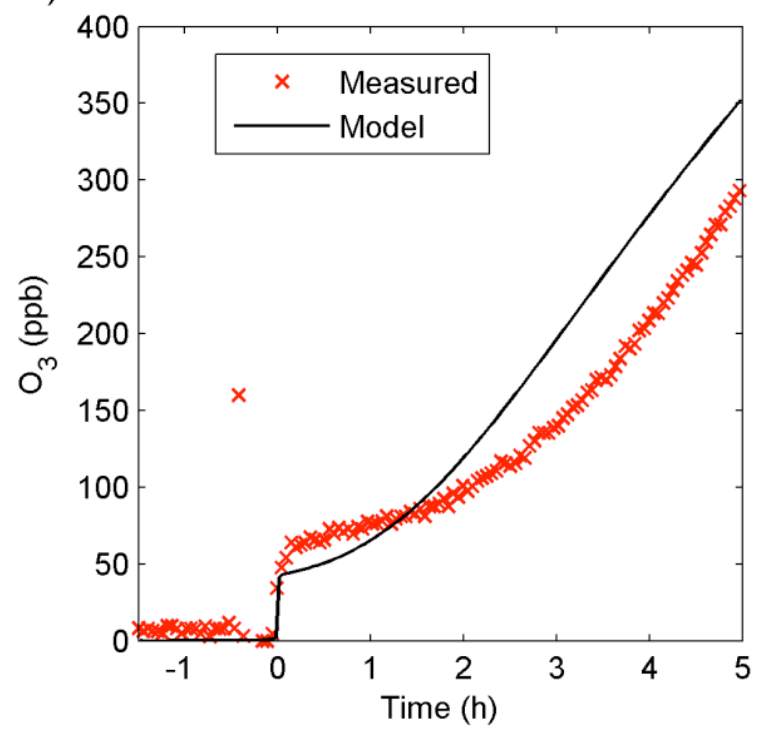

d)

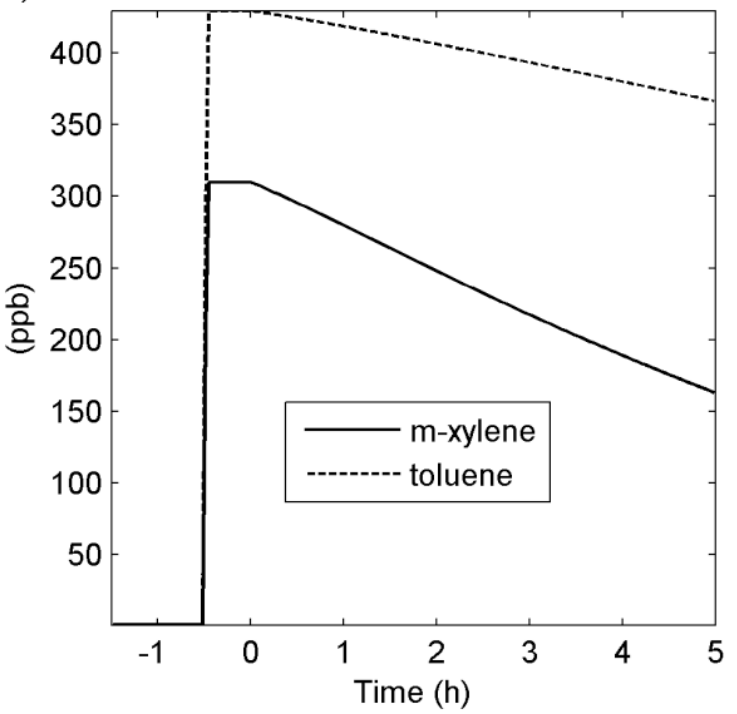

3 Figure $\mathrm{S}$ 3. Modelled (a) $\mathrm{NO}(\mathrm{g})$, (b) $\mathrm{O}_{3}(\mathrm{~g})$, (c) $\mathrm{OH}(\mathrm{g})$ and (d) $m$-xylene(g) and toluene(g)

4 concentrations for the DEP2 experiment. In (a) and (b) the modelled concentrations can be 5 compared with the measured. The UV onset is at time $0 \mathrm{~h}$ in the figures. 


\section{Particle-phase chemistry and SOA formation}

2 Oxidation products from the added light-aromatic precursors $\mathrm{m}$-xylene and toluene dominate

3 the SOA formed during the DEP2 experiment. However a small fraction of the SOA is also

4 originating from other organic compounds present in the diesel exhausts (e.g. $n$-alkanes and

5 PAHs).

6 The SOA formation from $m$-xylene and toluene are modelled by considering the non-

7 equilibrium gas-particle partitioning of all their non-radical oxidation products in MCMv3.2.

8 In Roldin et al. (2014) it was shown that ADCHAM could not capture the observed early

9 stage SOA formation during an $m$-xylene oxidation experiment, if not considering particle-

10 phase oligomerization. However, with peroxyhemiacetal (aldehydes + hydroperoxides) and

11 hemiacetal (alcoholes + aldehydes) dimer formation rates $\left(k_{f}\right)$ of $10^{-22} \mathrm{~cm}^{3} \mathrm{~s}^{-1}$, ADCHAM

12 were able to nearly reproduce the temporal evolution of the SOA concentration during the

13 complete oxidation experiment ( $\sim 4$ hours). Here we will test to simulate the SOA formation

14 both with and without these particle-phase oligomerization processes.

15 In order to account for the SOA formation from known PAHs and $n$-alkanes measured in 16 diesel exhausts, we use the measurements from Schauer et al. (1999). Eq. (S1) is used for 17 estimating the absolute $n$-alkane and PAH concentrations in the chamber. Table $\mathrm{S} 4$ gives the 18 estimated initial PAH and $n$-alkane concentrations, and their first order reaction rate with $\mathrm{OH}$ 19 radicals $\left(k_{O H, i}\right)$.

21 Table S 4. Estimated initial PAH and $n$-alkane concentrations in the Teflon chamber during the DEP2 and DEP4 experiments, and $k_{O H, i}$ used in the model simulations.

\begin{tabular}{lll}
\hline & $c_{i}(\mathrm{ppbv})$ & $k_{O H, i}\left(\mathrm{~cm}^{3} \mathrm{molec}^{-1} \mathrm{~s}^{-1}\right)$ \\
\hline PAHs & & \\
Naphthalene & 0.2054 & $2.3 \times 10^{-11(\mathrm{a})}$ \\
2-methylnaphthalene & 0.1860 & $4.86 \times 10^{-11(\mathrm{~b})}$ \\
1-methylnaphthalene & 0.1151 & $4.09 \times 10^{-11(\mathrm{~b})}$ \\
C2-naphthalene & 0.1520 & $6.0 \times 10^{-11(\mathrm{c})}$ \\
C3-naphthalene & 0.0624 & $8.0 \times 10^{-11(\mathrm{~d})}$ \\
C4-naphthalene & 0.0236 & $8.0 \times 10^{-11(\mathrm{~d})}$ \\
other PAHs & 0.2010 & $8.0 \times 10^{-11(\mathrm{~d})}$ \\
Total & $\mathbf{0 . 9 4 5 3}$ & \\
& & \\
$n$-alkanes & & $1.32 \times 10^{-11(\mathrm{a})}$ \\
Dodecane & 0.1276 & $1.51 \times 10^{-11(\mathrm{a})}$ \\
Tridecane & 0.1117 & $1.79 \times 10^{-11(\mathrm{a})}$ \\
Tetradecane & 0.1368 & \\
\hline
\end{tabular}




\begin{tabular}{lll}
\hline Pentadecane & 0.0808 & $2.07 \times 10^{-11(\mathrm{a})}$ \\
Hexadecane & 0.1353 & $2.32 \times 10^{-11(\mathrm{a})}$ \\
Heptadecane & 0.1099 & $2.85 \times 10^{-11(\mathrm{e})}$ \\
Octadecane & 0.1016 & $3.51 \times 10^{-11(\mathrm{e})}$ \\
Nonadecane & 0.0658 & $4.32 \times 10^{-11(\mathrm{e})}$ \\
Eicosane & 0.0414 & $5.31 \times 10^{-11(\mathrm{e})}$ \\
Total & $\mathbf{0 . 9 1 0 8}$ & \\
\hline
\end{tabular}

1 (a) Atkinson and Arey (2003)

2 (b) Phousongphouang and Arey (2002)

3 (c) Average of all dimethylnaphthalanes in Phousongphouang and Arey (2002)

$4 \quad{ }^{(d)}$ Estimated from dimethylnaphthalenes, assumed to be same for all other PAHs according to Chan et al. (2009)

$5{ }^{(\mathrm{e})}$ Estimated from structure-reactivity relationships (Kwok and Atkinson, 1995)

7 The SOA formation from the PAHs were modelled with the one or two product SOA yield 8 parameterizations from Chan et al. (2009), for high- $\mathrm{NO}_{\mathrm{x}}$ conditions. For the n-alkanes we 9 estimate the SOA yields based on the modelling from Jordan et al. (2008), using a 1-product 10 model parameterization (Eq. (S2)),

$11 Y_{i}=M_{o} \frac{\alpha_{i} K_{i}}{1+K_{i} M_{o}}$

12 where $\alpha_{i}$ is the mass-based stoichiometric yield of the oxidation product $i, K_{i}$ is its gas-particle 13 partitioning equilibrium constant, and $M_{o}$ is the total particulate organic mass concentration 14 (listed in Table S5).

16 Table S 5. Estimated mass-based stoichiometric yields $\left(\alpha_{\mathrm{i}}\right)$, equilibrium partitioning constants $17 \quad\left(\mathrm{~K}_{\mathrm{i}}\right)$ and pure liquid saturation vapour pressures $\left(\mathrm{p}_{0, \mathrm{i}}\right)$, derived from the SOA yield 18 parameterizations of different n-alkanes (Eq. (S2)).

\begin{tabular}{llll}
\hline$c_{i}$ & $\alpha_{i}$ & $K_{i}\left(\mathrm{~m}^{3} \mu \mathrm{g}^{-1}\right)$ & $p_{0, i}(\mathrm{~Pa})$ \\
\hline Dodecane & 0.0472 & 0.0489 & $2.109 \times 10^{-4}$ \\
Tridecane & 0.0898 & 0.0333 & $2.925 \times 10^{-4}$ \\
Tetradecane & 0.1536 & 0.0320 & $2.883 \times 10^{-4}$ \\
Pentadecane & 0.2775 & 0.0272 & $3.221 \times 10^{-4}$ \\
Hexadecane & 0.3531 & 0.0341 & $2.447 \times 10^{-4}$ \\
Heptadecane & 0.4402 & 0.0554 & $1.437 \times 10^{-4}$ \\
Octadecane & 0.5430 & 0.0823 & $9.25 \times 10^{-5}$ \\
Nonadecane & 0.6280 & 0.1350 & $5.41 \times 10^{-5}$ \\
Eicosane & 0.7837 & 0.1668 & $4.20 \times 10^{-5}$ \\
\hline
\end{tabular}

ADCHAM includes a kinetic multilayer model, which considers the diffusion of compounds

20 between different particle layers. For the model simulations performed here each particle is 21 treated as composed of one solid soot core, one amorphous organic bulk phase layer and one 22 particle surface monolayer, with limited diffusion between the layers. The aerosol dynamic 
1 processes considered are: Brownian coagulation, condensation/evaporation and dry deposition

2 to the chamber walls. For more details see Roldin et al. (2014).

3 Before the onset of UV radiation in the chamber a substantial increase of the $\mathrm{O}: \mathrm{C}$ ratio from $4 \sim 0.05$ to $\sim 0.2$ is observed, meanwhile the $\mathrm{H}: \mathrm{C}$ ratio decreases from $\sim 1.9$ to $\sim 1.75$ (see Fig. S4d). However, no particle mass increase or change in the mass spectra is observed during this time, other than a slight increase in $\mathrm{m} / \mathrm{z} 44$ due to $\mathrm{CO}_{2}{ }^{+}$. According to the ADCHAM model simulations there were very low concentrations of $\mathrm{NO}_{3}$ radicals $\left(<10^{6}\right.$ molecules $\left.\mathrm{cm}^{-3}\right)$,

$8 \mathrm{OH}\left(<3000\right.$ molecules $\left.\mathrm{cm}^{-3}\right)$ and $\mathrm{O}_{3}(<1 \mathrm{ppbv})$, before the UV-light was turned on. Hence, the change in $\mathrm{O}: \mathrm{C}$ and $\mathrm{H}: \mathrm{C}$ ratio during the dark conditions is unlikely attributed to SOA formation. Instead it can be explained by heterogeneous oxidation of POA with $\mathrm{NO}_{2}$, which reaches a maximum concentration of $\sim 500 \mathrm{ppb}$, just before the onset of the UV-lights. The heterogeneous oxidation of diesel soot coated with POA has previously primarily been studied because of the potential importance for HONO formation (e.g. Arens et al., 2001; Han et al., 2013).

For the simulations presented here it is assumed that the POA is composed of slightly oxidized $n$-alkanes, and alkenes with an average number of carbon atoms per molecule of 26 , two carbon-carbon double bonds, and one ketone functional group $(\mathrm{H}: \mathrm{C}=1.8846$, $\mathrm{O}: \mathrm{C}=0.0385)$. The POA are assumed to react with $\mathrm{NO}_{2}$ with a reaction rate $\left(k_{\mathrm{NO}_{2}}\right)$ equal to $10^{-18} \mathrm{~cm}^{-3} \mathrm{~s}^{-1}$, forming oxidized POA (OPOA) with an $\mathrm{H}: \mathrm{C}$ of 1.6538 and O:C of 0.1923 . The uptake of $\mathrm{NO}_{2}$ is modelled with the kinetic multilayer model, considering the adsorption and diffusion of $\mathrm{NO}_{2}$ between the surface monolayer and the organic bulk phase, analogous to Roldin et al. (2014). The $\mathrm{NO}_{2}$ diffusion coefficient was assumed to be equal to $10^{-8} \mathrm{~cm}^{2} \mathrm{~s}^{-1}$.

Figure S4 shows the modelled and measured: (a) particle number concentration, (b) total organic particle mass concentration in the air, (c) organic mass fraction $\left(\mathrm{mf}_{\mathrm{OA}}\right)$ and $(\mathrm{d}) \mathrm{H}: \mathrm{C}$ and O:C ratios. When accounting for deposition of charged and neutral particles two the chamber walls, according to the procedure described in Roldin et al. (2014) (although with five times larger friction velocity) and Brownian coagulation, the modelled particle number concentrations are in good agreement with the observations. The model performance substantially improves if we consider hemiacetal and peroxyhemiacetal (oligomer) formation. However, in contrast to the $m$-xylene experiment in Roldin et al. (2014), ADCHAM still substantially underestimates the total organic particle mass and $\mathrm{mf}_{\mathrm{OA}}$ (SOA formation) $0-2$ hour after the UV exposure starts. 
1 Figure S 5 shows the temporal evolution of the modelled mass concentration of POA,

2 OPOA and SOA formed from oxidation products of light-aromatic compounds ( $m$-xylene and

3 toluene), $n$-alkanes and PAHs. According to the model results the mass contribution from $n$ -

4 alkane oxidation products are negligible, and the contribution from the considered PAHs

5 (Table S3) are $\sim 4$ times too small to explain the observed early stage SOA formation. This

6 indicates that we either substantially underestimates the PAH concentrations in the chamber

7 or that there are some unknown IVOCs in the Diesel exhausts which we do not account for.

8 Another possibility could also be that we cannot realistically represent the early stage SOA

9 formation from the $m$-xylene and toluene oxidation products. Possibly, a reactive uptake 10 mechanism not directly driven by the oxidation products saturation vapour pressures but their 11 reactivity with other organic compounds on the particle surfaces, could explain the almost 12 immediate onset of the SOA formation, after the UV-light is turned on. However, this is not 13 fully consistent with the $m$-xylene experiment simulated in Roldin et al. (2014), or other 14 classical photooxidation experiments of light-aromatic compounds (see e.g. Ng et al., 2007). 15 Figure S6 shows the measured and modelled total organic particle mass plotted against the 16 amount of reacted $m$-xylene and toluene ( $\Delta m$-xylene $+\Delta$ toluene). According to the model 17 simulations $\sim 120 \mu \mathrm{g} / \mathrm{m}^{3}$ of $m$-xylene and $\sim 40 \mu \mathrm{g} / \mathrm{m}^{3}$ of toluene have been consumed before 18 the OA mass starts to increase in the air. However from the measurements in combination 19 with the modelled $m$-xylene and toluene decay, only $\sim 30 \mu \mathrm{g} / \mathrm{m}^{3}$ of $m$-xylene and $\sim 10 \mu \mathrm{g} / \mathrm{m}^{3}$ of 20 toluene need to react before the OA mass increases. 

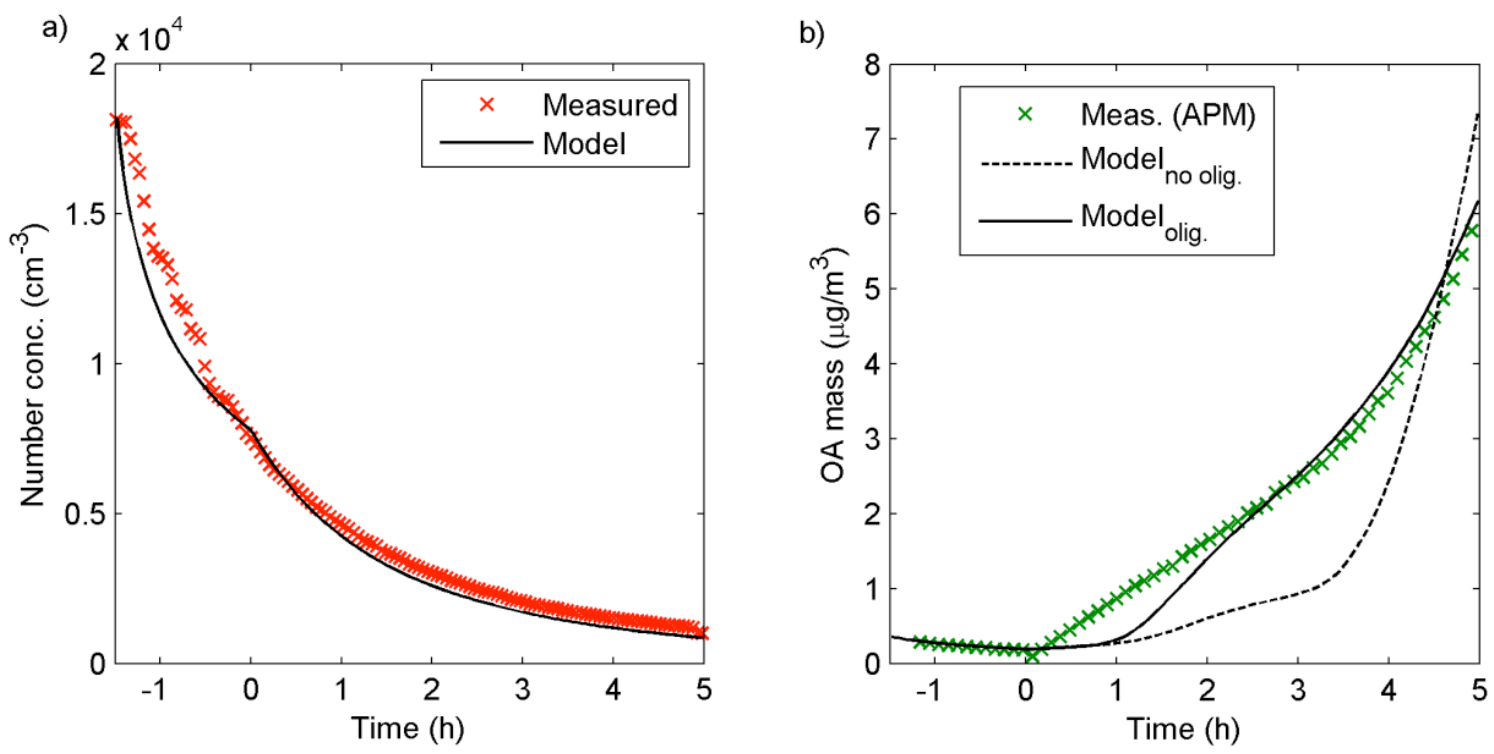

c)

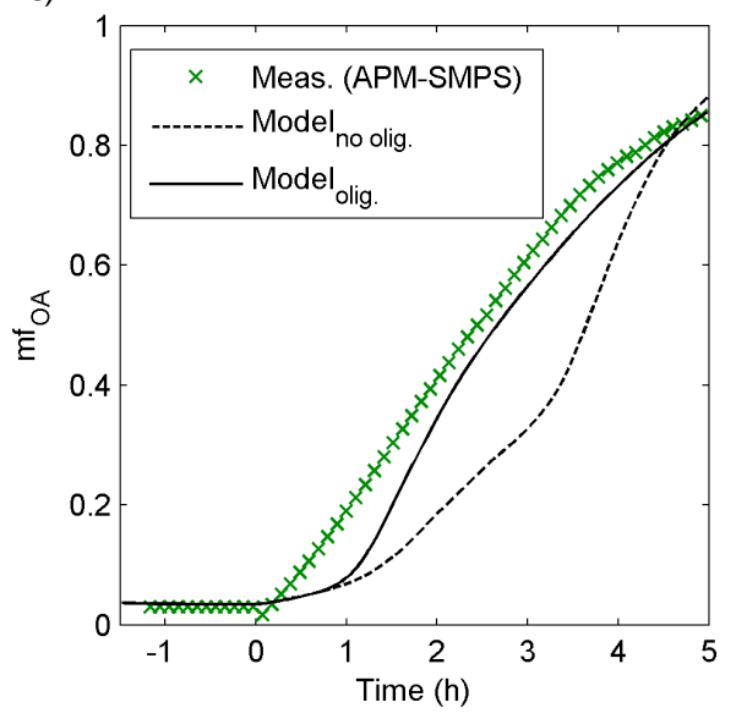

d)

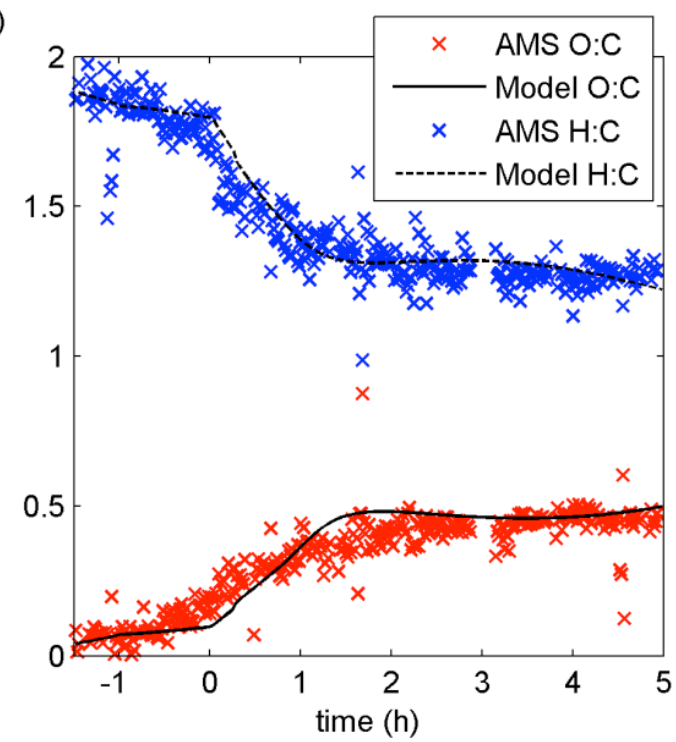

3 Figure S 4. Modelled and measured (a) particle number concentration, (b) OA mass, (c) $\mathrm{mf}_{\mathrm{OA}}$ 4 and (d) $\mathrm{H}: \mathrm{C}$ and $\mathrm{O}: \mathrm{C}$ ratios for the DEP2 experiment. The onset of UV exposure is at time $0 \mathrm{~h}$ 5 in the figures. In (b) and (c) the model results from simulations with (solid line) and without 6 (dashed line) particle phase oligomerization are included. In (a) and (d) the results are from 7 the simulation with oligomerization. 


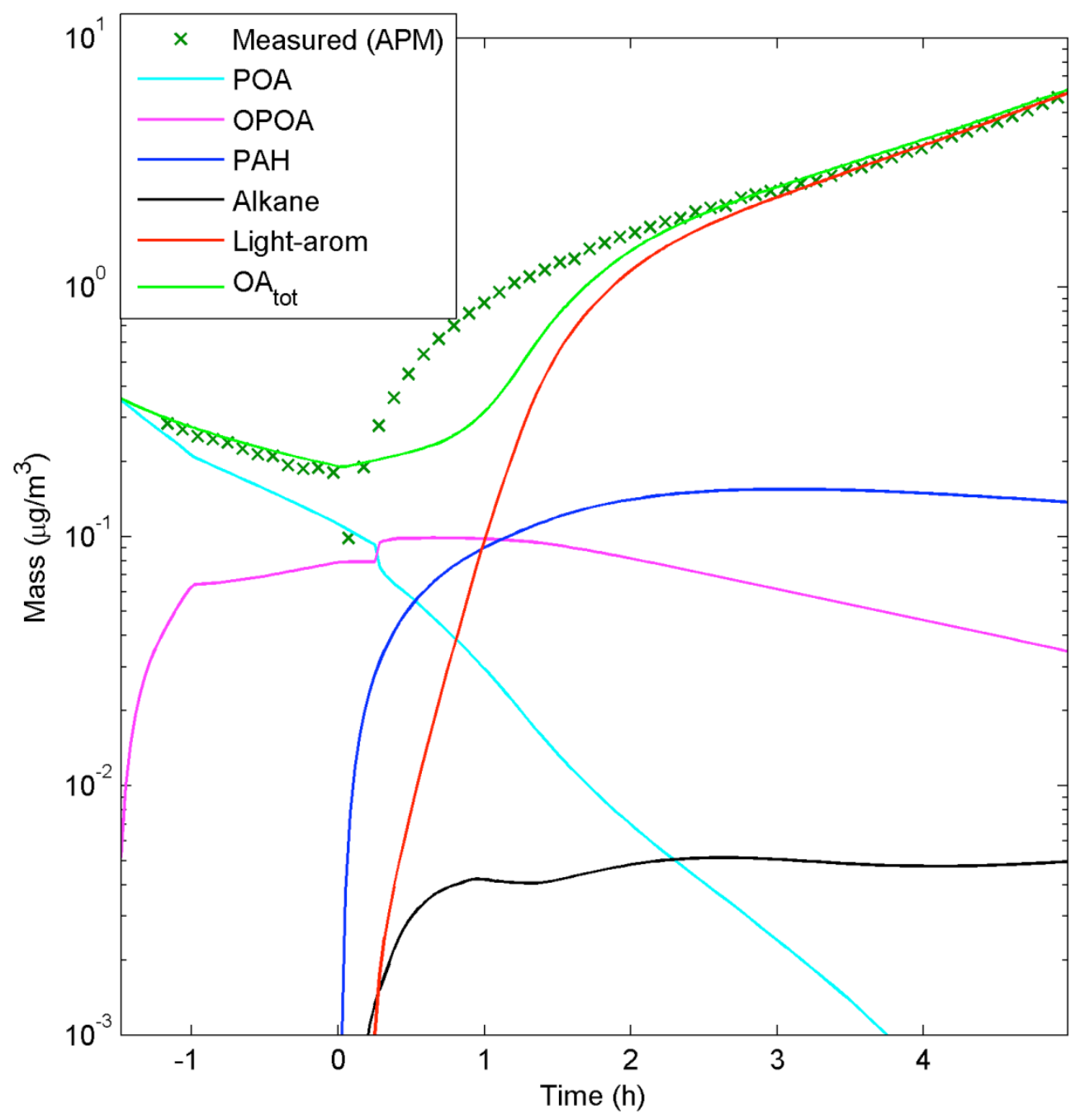

3 Figure S 5. Modelled (lines) and measured (markers; APM-SMPS) total organic particle mass 4 (in the air) for the DEP2 experiment. Given are also the modelled POA (turquoise), OPOA 5 (pink) formed from the heterogeneous reactions between $\mathrm{POA}$ and $\mathrm{NO}_{2}$, and $\mathrm{SOA}$ originating 6 from the light-aromatic precursors (m-xylene and toluene) (red), PAHs (blue) and $n$-alkanes 7 (black). We have also included the modelled total organic mass (light green) in the air and on 8 the wall deposited particles. At time $0 \mathrm{~h}$ in the figure the UV-lights are turned on. 


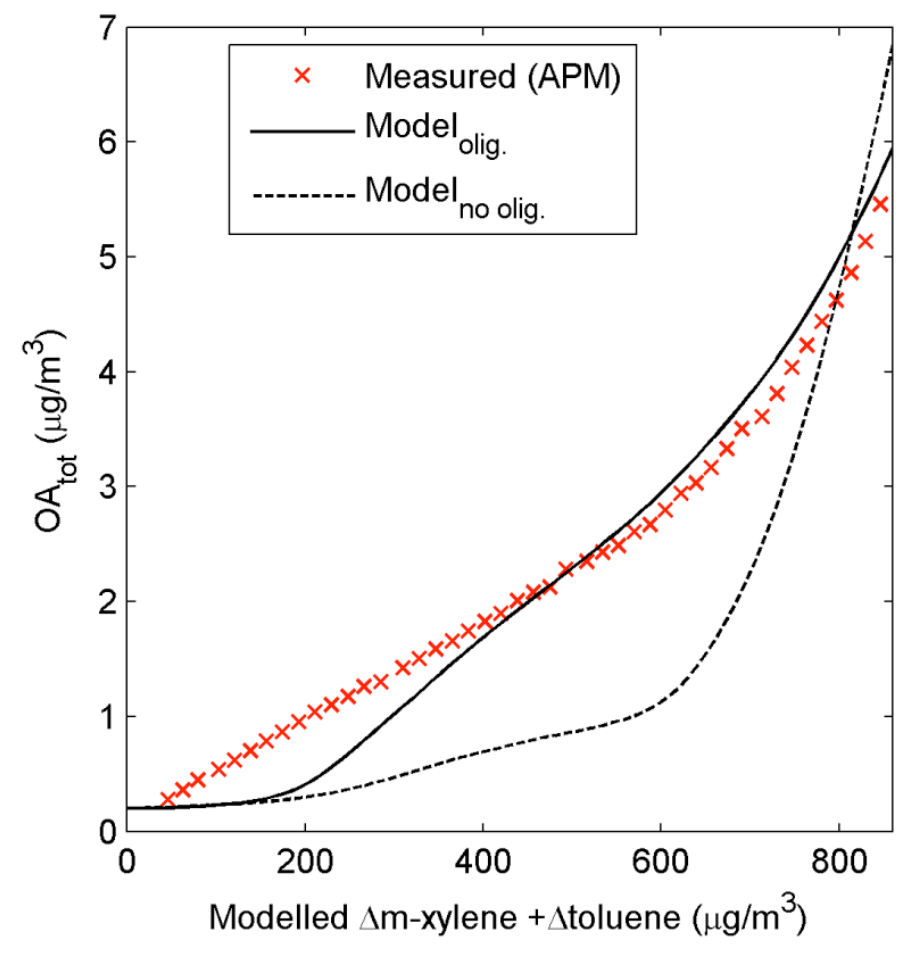

2

3 Figure S 6. Measured (APM) and modelled total organic particle mass concentration $\left(O A_{\text {tot }}\right)$ 4 plotted against the amount of reacted $m$-xylene and toluene.

5 


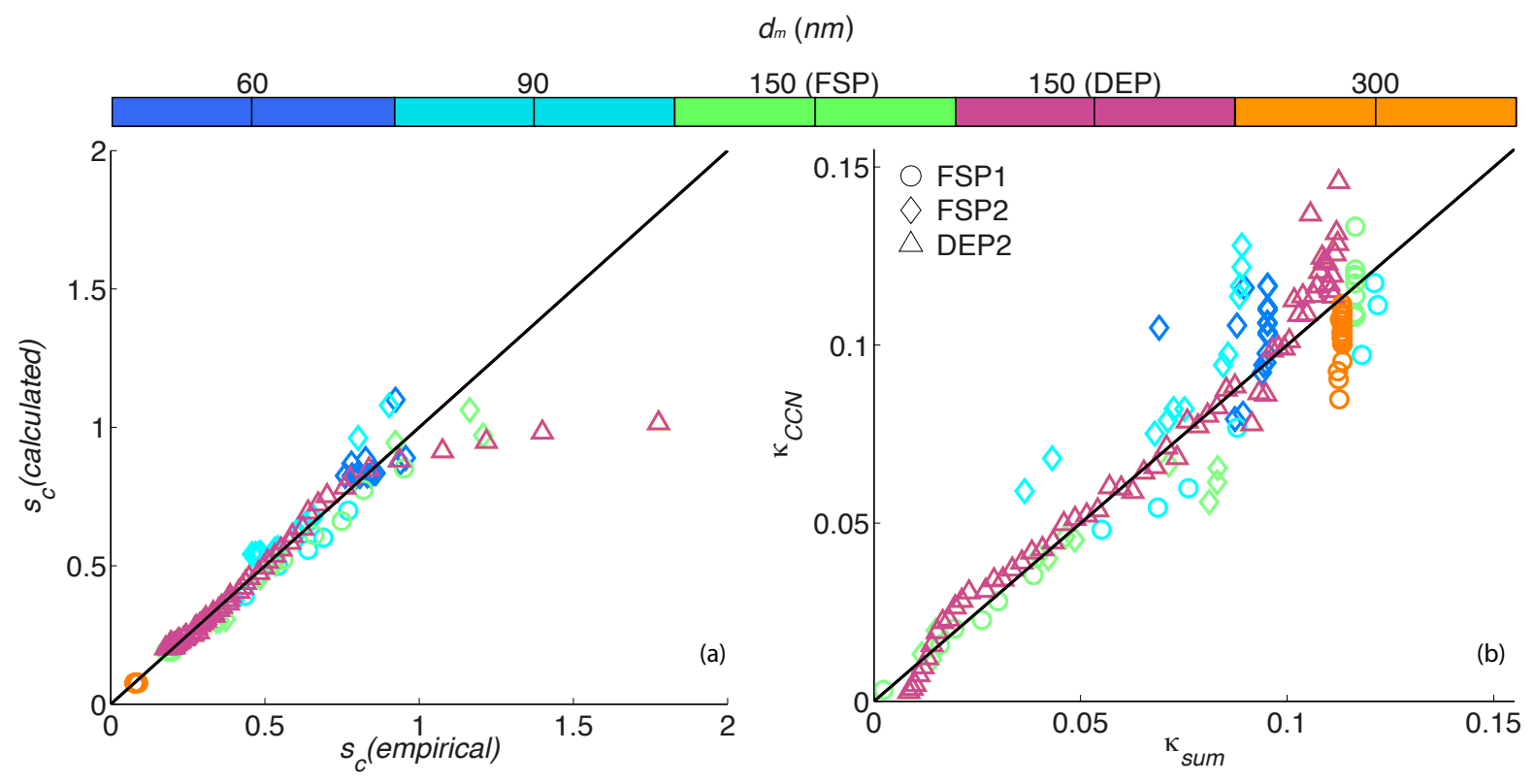

3 Figure S 7. Comparison of calculated $s_{c}$ and empirical results (a) and comparison of $\kappa_{S O A}$ with $4 \kappa_{C C N}(\mathbf{b})$, calculated from the chemical composition and measured $s_{c}$ respectively. Colour code 5 with respect to particle mobility diameter $\left(d_{\mathrm{m}}\right)$ and different markers with respect to type of 6 soot generator (experiment FSP1, 2 or DEP2). The large discrepancies for the high values of $7 \quad s_{c}$ in (a) are due to the under prediction of the $s_{c}$ by the model of the early aged soot particles. 8 Small values in (b) correspond to modelled and measured values ( $\kappa_{S O A}$ and $\left.\kappa_{C C N}\right)$ for early aged soot particles, where uncertainties are large for $\kappa_{C C N}$. For large values in (b) the uncertainties are inherited from empirical fitting of the $\mathrm{mf}_{\mathrm{SOA}}$ (visible for FSP $1 ; d_{\mathrm{m}}=150$ and $300 \mathrm{~nm}$, and for FSP2; $d_{\mathrm{m}}=60$ and $90 \mathrm{~nm}$ ).

\section{Determining $\mathrm{mf}_{\mathrm{OA}}$ from the SP-AMS data}

14 Quantification by means of AMS is a two-step process. First, the signal is assigned to species 15 (such as 'organics', 'rBC' etc., see next paragraph), using the fragmentation table approach 16 (Allan et al., 2004). Then, a species is quantified using two parameters: collection efficiency 17 (CE) and ionization efficiency (IE) (Allan et al., 2004). CE refers to the fraction of the mass that is eligible for ionization, normally dominated by bounce of the tungsten vaporizer (Huffman et al., 2005). For PM vaporized by the SP-module, the main issue is overlap of particle and laser beams. IE is the probability that ionization occurs, decoupled from CE (i.e. given that the material is not bouncing of the tungsten vaporizer, missing the laser beam etc.) 
1 Since ammonium nitrate is the default calibration substance, IEs are often expressed in terms of relative ionization efficiencies compared to nitrate.

Refractory Black Carbon (rBC) mass loadings were estimated assuming a relative ionization efficiency (compared to nitrate) of 0.2 , applied to the $\mathrm{C}_{1-9}{ }^{+}$ions (signal due to $\mathrm{C}_{>9}$ was negligible) after accounting for the organic contribution to $\mathrm{C}_{1}{ }^{+}$(the contribution to $\mathrm{C}_{2-9}{ }^{+}$was negligible). $\mathrm{C}_{1}^{+}$was apportioned to $\mathrm{rBC}$ as $70 \%$ of $\mathrm{C}_{3}{ }^{+},\left(\mathrm{C}_{3}{ }^{+}\right.$was chosen because it is the most abundant) the remaining signal from $\mathrm{C}_{1}{ }^{+}$was interpreted as organic. This was based on measurements on fresh soot in each experiment, where the organic contribution to $\mathrm{C}_{1}^{+}$was negligible. $\mathrm{rBC}$ also generated $\mathrm{CO}_{2}{ }^{+}$ions (and presumably $\mathrm{CO}^{+}$, but these were not retrieved owing to the interference from $\mathrm{N}_{2}^{+}$), these were found to correspond to $70-90 \%$ of $\mathrm{C}_{3}{ }^{+}$. These $\mathrm{CO}_{2}{ }^{+}$ions where excluded from the results presented here, pending further investigation. A $\mathrm{CE}$ of 1 was applied for both organics and $\mathrm{rBC}$.

\section{Determining $\mathrm{mf}_{\mathrm{OA}}$ from combined DMA-APM and SMPS measurements}

The total organic mass fraction of the polydisperse particle size distribution was determined from a procedure that started with determining the mass size distribution by multiplying the measured number size distribution from the SMPS with the size resolved mass per particle determined with the DMA-APM. This mass size distribution was then divided into a volatile (organic) and a non-volatile fraction by, in a size resolved manner, multiplying the mass distribution with the volatile mass fraction for each size bin. The DMA-TD-APM measured in the size range 60 to $300 \mathrm{~nm}$ at five discrete mobility sizes. Data at other sizes were obtained by fitting a physically relevant function.

\section{Corresponding atmospheric ageing timescales}

25 The modelled cumulative $\mathrm{OH}$ exposure during the end of the DEP2 experiment is $7.7 \times 10^{6} \mathrm{~cm}^{-}$

${ }^{3} \mathrm{~h}$. This together with the measured mass spectral signature of the organic material (see Sect.

5.2) illustrate that, with respect to chemical composition, the SOA during the experiment is relatively fresh (a few hours of ageing for typical summer daytime conditions). Still, for midlatitude winter conditions this cumulative $\mathrm{OH}$ exposure may very well correspond to one or a few days in the atmosphere.

31 In the smog chamber experiments the SOA precursor concentration is substantially higher than for typical atmospheric conditions, while the condensation sinks of the diesel soot particles, are comparable with typical urban plume conditions (see e.g. Roldin et al., 2011). 
1 Hence, substantially higher mass growth rates are expected in the chamber compared to

2 typical atmospheric urban plume conditions. To some extent this is counteracted by the 3 uptake of condensable organic compounds onto the Teflon walls and wall deposited particles.

4 In the smog chamber the time of photochemical ageing, before the soot particles become $5 \mathrm{CCN}$ active at a supersaturation of $0.2 \%$, range from 1.5 to $>4.5 \mathrm{~h}$ depending on experimental 6 conditions as well as particle size. To estimate the corresponding atmospheric ageing time the 7 range of observed new particle growth rates (GR) in the mid-latitudes of $1-20 \mathrm{~nm} / \mathrm{h}$ has been 8 used (Kulmala et al., 2004). It is also assumed that these growth rates (if converted to mass 9 growth rates) are valid for soot particles with a mobility diameter $\left(d_{\mathrm{m}}\right)$ of $\sim 100 \mathrm{~nm}$ (volume 10 equivalent diameter $\left(d_{v e, f r e s h}\right)$ of $\left.\sim 70 \mathrm{~nm}\right)$. According to the experiments these particles need

11 to have an $\mathrm{mf}_{\mathrm{SOA}}$ of $\sim 90 \%$ before they activate at a supersaturation of $0.2 \%$ (see Figure 11 ).

12 At this stage these particles have a volume equivalent diameter $\left(d_{v e \text {,aged }}\right)$ equalling the 13 mobility diameter $\left(d_{\mathrm{m}}\right)$ of $\sim 150 \mathrm{~nm}$, i.e. the particles are almost spherical. Hence, based on 14 this the atmospheric ageing time with respect to organic condensational growth $\left(t_{\text {atm }}\right)$ is 15 estimated to be between 4 hours and 3 days (Eq. (S3)).

$16 t_{a t m}=\frac{\left(d_{v e, \mathrm{aged}}-d_{v e, \text { fresh }}\right)}{G R}$ 


\section{References Supplementary}

Allan, J. D., Delia, A. E., Coe, H., Bower, K. N., Alfarra, M. R., Jimenez, J. L., Middlebrook, A. M., Drewnick, F., Onasch, T. B., Canagaratna, M. R., Jayne, J. T. and Worsnop, D. R. "A generalised method for the extraction of chemically resolved mass spectra from aerodyne aerosol mass spectrometer data." Journal of Aerosol Science 35, no. 7 (Jul 2004): 909-922.

Arens, F., Gutzwiller, L., Baltensperger, U., Gaggeler, H. W. and Ammann, M. "Heterogeneous reaction of NO2 on diesel soot particles." Environmental Science \& Technology 35, no. 11 (Jun 1 2001): 2191-2199.

Atkinson, R. and Arey, J. "Atmospheric degradation of volatile organic compounds." Chemical Reviews 103, no. 12 (Dec 2003): 4605-4638.

Bloss, C., Wagner, V., Bonzanini, A., Jenkin, M. E., Wirtz, K., Martin-Reviejo, M. and Pilling, M. J. "Evaluation of detailed aromatic mechanisms (MCMv3 and MCMv3.1) against environmental chamber data." Atmospheric Chemistry and Physics 5 (Mar 1 2005a): 623-639.

Bloss, C., Wagner, V., Jenkin, M. E., Volkamer, R., Bloss, W. J., Lee, J. D., Heard, D. E., Wirtz, K., Martin-Reviejo, M., Rea, G., Wenger, J. C. and Pilling, M. J. "Development of a detailed chemical mechanism (MCMv3.1) for the atmospheric oxidation of aromatic hydrocarbons." Atmospheric Chemistry and Physics 5 (Mar 1 2005b): 641-664.

Chan, A. W. H., Kautzman, K. E., Chhabra, P. S., Surratt, J. D., Chan, M. N., Crounse, J. D., Kurten, A., Wennberg, P. O., Flagan, R. C. and Seinfeld, J. H. "Secondary organic aerosol formation from photooxidation of naphthalene and alkylnaphthalenes: implications for oxidation of intermediate volatility organic compounds (IVOCs)." Atmospheric Chemistry and Physics 9, no. 9 (2009): 3049-3060.

Han, C., Liu, Y. C. and He, H. "Role of Organic Carbon in Heterogeneous Reaction of NO2 with Soot." Environmental Science \& Technology 47, no. 7 (Apr 2 2013): 3174-3181.

Huffman, J. A., Jayne, J. T., Drewnick, F., Aiken, A. C., Onasch, T., Worsnop, D. R. and Jimenez, J. L. "Design, modeling, optimization, and experimental tests of a particle beam width probe for the aerodyne aerosol mass spectrometer." Aerosol Science and Technology 39, no. 12 (Dec 2005): 1143-1163.

Jenkin, M. E., Saunders, S. M., Wagner, V. and Pilling, M. J. "Protocol for the development of the Master Chemical Mechanism, MCM v3 (Part B): tropospheric degradation of aromatic volatile organic compounds." Atmospheric Chemistry and Physics 3 (Feb 12 2003): 181-193.

Jordan, C. E., Ziemann, P. J., Griffin, R. J., Lim, Y. B., Atkinson, R. and Arey, J. "Modeling SOA formation from $\mathrm{OH}$ reactions with C-8-C-17 n-alkanes." Atmospheric Environment 42, no. 34 (Nov 2008): 8015-8026.

Kroll, J. H., Donahue, N. M., Jimenez, J. L., Kessler, S. H., Canagaratna, M. R., Wilson, K. R., Altieri, K. E., Mazzoleni, L. R., Wozniak, A. S., Bluhm, H., Mysak, E. R., Smith, J. D., Kolb, C. E. and Worsnop, D. R. "Carbon oxidation state as a metric for describing the chemistry of atmospheric organic aerosol." Nature Chemistry 3, no. 2 (Feb 2011): 133-139. 
Kulmala, M., Vehkamaki, H., Petaja, T., Dal Maso, M., Lauri, A., Kerminen, V. M., Birmili, 2 W. and McMurry, P. H. "Formation and growth rates of ultrafine atmospheric particles: a 3 review of observations." Journal of Aerosol Science 35, no. 2 (Feb 2004): 143-176.

4 Kwok, E. S. C. and Atkinson, R. "Estimation of Hydroxyl Radical Reaction-Rate Constants 5 for Gas-Phase Organic-Compounds Using a Structure-Reactivity Relationship - an Update.".

6 Atmospheric Environment 29, no. 14 (Jul 1995): 1685-1695.

Matsunaga, A. and Ziemann, P. J. "Gas-Wall Partitioning of Organic Compounds in a Teflon 8 Film Chamber and Potential Effects on Reaction Product and Aerosol Yield Measurements." 9 [In English]. Aerosol Science and Technology 44, no. 10 (2010): 881-892. "Secondary organic aerosol formation from m-xylene, toluene, and benzene." Atmospheric Chemistry and Physics 7, no. 14 (2007): 3909-3922.

Phousongphouang, P. T. and Arey, J. "Rate constants for the gas-phase reactions of a series of alkylnaphthalenes with the $\mathrm{OH}$ radical." Environmental Science \& Technology 36, no. 9 (May 1 2002): 1947-1952.

Rissler, J., Messing, M. E., Malik, A. I., Nilsson, P. T., Nordin, E. Z., Bohgard, M., Sanati, M. and Pagels, J. H. "Effective Density Characterization of Soot Agglomerates from Various Sources and Comparison to Aggregation Theory." Aerosol Science and Technology 47, no. 7 (Jul 1 2013): 792-805.

Roldin, P., Eriksson, A. C., Nordin, E. Z., Hermansson, E., Mogensen,D., Rusanen, A., Boy, M., Swietlicki, E., Svenningsson, B., Zelenyuk, A., and Pagels, J. "Modelling nonequilibrium secondary organic aerosol formation and evaporation with the aerosol dynamics, gas- and particle-phase chemistry kinetic multilayer model ADCHAM", Atmos. Chem. Phys., 14, 7953-7993, doi:10.5194/acp-14-7953-2014, 2014.

Roldin, P., Swietlicki, E., Massling, A., Kristensson, A., Londahl, J. L., Eriksson, A., Pagels, 27 J. and Gustafsson, S. "Aerosol ageing in an urban plume - implication for climate." 28 Atmospheric Chemistry and Physics 11, no. 12 (2011): 5897-5915. from air pollution sources. 2. C-1 through C-30 organic compounds from medium duty diesel trucks." Environmental Science \& Technology 33, no. 10 (May 15 1999): 1578-1587. 